\title{
A REVIEW OF THE RUSSIAN TAXATION REGULATORY DOCUMENTS ADOPTED IN JULY-AUGUST 2015
}

\author{
L.Anisimova
}

The Russian economy, according to the Russian Economic Development Ministry, "has hit the bottom, and Q4 results will be markedly better than the Q3 ones"1. It is telling that the situation developed at the end of August almost mirrors that at the end of December 2014, but there has been no panic so far. Russia's international reserves remain at $\$ 362 \mathrm{bn}$, the Russian Central Bank has not interfered with the ruble exchange rate. As of $\mathrm{H} 1$ end, 2015, some enterprises have began to show profits, thus contributing to a better picture of regional budgets which have begun to receive advanced payments on the profit tax.

The Russian government appears not yet to be ready to drastically cut budget spending ${ }^{2}$. Expenditure restraint measures provided for by the anti-crisis plan were launched in July-August 2015, but the level and the scheme of the restraints are unlikely to be able to release the overall tax burden on manufacturers. For instance, it is set forth in the plan of anti-crisis measures that some social-oriented compensations will cease to be indexed beginning with 2015 and amounts due will be carried forward and recovered in future periods ${ }^{3}$. It is obvious that the expenditure have no critical effect on the federal budget deficit. As a reminder, the IMF recommended the Russian authorities to cut government spending by $10 \%$ of GDP .

Budget sustainability amid crisis can be achieved by retaining the revenue base of budgets in addition to spending cuts. This is a challenge indeed. The Russian government in times of crisis is experiencing harder pressure by major taxpayers such as mineral extraction monopolies seeking ways to ease the tax burden on the activities they consider most critical, in particular,

1 "Ulyukayev: the Russian economy has hit the bottom". Available at: izvestia.ru/news/590385 dated 25 August 2015.

2 First and foremost: increase the retirement age, reduce the number of supervisory and control entities, government staff costs, abandon the priority support to mineral extraction and financial state-run corporations.

3 Russian Government Executive Order No. 840 dated 13 August 2015 suspended beginning with 2015 a few of the social-oriented legal acts of the Russian Government for the purpose of the Federal Law "On the Federal Budget for 2015 and the Planning Period of 2016 and 2017, including executive order dated 12 October 2010 No. 813 "On indexation of funeral costs and grants"; executive order dated 16 December 2014 No. 1371 “On indexation of the annual financial compensation to disabled persons for costs on guide-dog upkeeping and veterinary attendance; от 18 December 2014 No. 1411 "On indexation of compensations and other payments to the citizens exposed to radiation as a result of the disaster at the Chernobyl Nuclear Plant, the Production Association Mayak, and the disposal of radioactive waste in the Techa River, nuclear weapon tests at the Semipalatinsk test site.

4 Edovina T, "The IMF prepares budget cuts for Russia. Government spending are recommended to cut $10 \%$ of GDP", Available at: kommersant.ru/doc/2781656 от 4 August 2015. they want the mineral extraction tax to be abolished. Oil producers and the Russian Ministry of Industry and Trade (MinPromTorg) have ratcheted up their requirements for replacing the mineral extraction tax with the financial result tax (FRT). To prevent uncontrolled loss of budget revenues in the critical period of 2016, the Russian Finance Ministry (MinFin) has suggested that a bill on added income tax (AIT) as replacement of the FRT should be drafted and approved in $2016^{5}$ as an alternative to the "tax maneuver" proposed by the oil producing community.

While the mineral extraction tax involves payment of a fixed amount per each ton of produced crude oil, the FRT and the AIT link the tax amount with total revenues generated by a project. The FRT is a tax levied on the difference between oil sales revenues and costs of oil production and transportation given accelerated depreciation of current (not accumulated) capital investment in a project ( $40 \%$ over 4 years). The FRT is applied to only active oil fields (with easy-to-access mineral resources). The AIT base is revenue less production costs and all capital investment, but the rate is floating and depends on P-factor (the accumulated revenue/accumulated costs ratio). In other words, tax burden will growth with profitability. It is our opinion that this is a more fair and holistic approach to oil production taxation which sets a higher tax rate on the production in fields with easy-to-access oil and a lower one on those with hard-to-access crude oil. However both approaches are exposed to the risk of unbalancing the current budget revenue base. Since the initial stage of implementing mineral extraction projects tends to involve high capital spending, one should expect budget sources to reduce considerably

5 Papchenkova M, Fadeyeva A., Starinskaya, "The MinFin proposes its version of tax reform for the oil sector. MinFin fears that the version approved by the Russian government may pose risks for the budget". Available at: vedomosti.ru/economics/ articles/2015/08/03/603159-minfin-predlozhit-svoyu-reformunalogooblozheniya-neftyanoi-otrasli dated 3 August 2015. 
compared to generating budget revenues from each ton of produced crude oil (as with the mineral extraction tax). It is therefore our opinion that it would be reasonable to continue employing the current scheme until the crisis is over.

In addition, one shouldn't overlook that the problem of replacing the mineral extraction tax with the FRT or the AIT involves another level of conflict of interests, i.e. between the federal budget and the regional budgets. The mineral extraction tax is a part of federal budget revenues, whereas the FRT and the AIT is the financial result (profit) tax on a project. Under the currently applicable tax law, the profit tax is levied at $18 \%$ to the regional budgets and at $2 \%$ to the federal budget.

Excise duties and the transportation tax are the key sources which feed regional road funds (the regions use such funds to finance road construction). The excise duties have been lowered by replacing customs duties with the mineral extraction tax. Unlike customs duties, the mineral extraction tax is recognized as costs, and therefore the replacement of the amount, which has ceased to be a part of the federal budget revenue, of tax duties levied on the selling price given the excise tax, with an amount equal to the mineral extraction tax, has resulted in higher costs. The introduction of mineral extraction tax has resulted in the excise duty being assessed from a bigger tax base. The excise tax has been reduced in order to prevent increase in the price of oil and petrochemicals. This has resulted in less revenues for regional road funds. For the purpose of compensating the regions for losses, they have been entitled to the entire excise duty on oil and gas condensate (the excise duty was previously shared among the federal budget and the regional budgets). According to specialists, the regional road funds' losses have not been compensated in full ${ }^{1}$. President Vladimir Putin has commissioned the Russian government to find a way of making inter-budget transfers from the federal budget to the regions for the purpose of road maintenance.

Moreover, there are more illustrations showing that the crisis has sharpened the issue of distributing the revenue base among the federal budget and the regional (local) budgets. Another line will be considered as part of the analysis of an updated version of the Guidelines of the Tax Policy in the Russian Federation for 2016 and the Planning Period of 2017 and 2018.

A serious channel of tax-free revenue flow out of the Russian Federation was blocked in July-August 2015. The Moscow District Commercial Court ruled that

1 Buranov I., "All the roads lead to money. Vladimir Putin commissions the government to find money by all means.". Available at: kommersant.ru/doc/2785180 dated 10 August 2015. expenses of a transnational corporation (TNC) head office located outside the Russian Federation, which are not confirmed by documents to meet the requirements of the Russian laws and regulations, should not be recognized as for tax purposes regarding the profit of the representative office of the transnational corporation (TNC) ${ }^{2}$. Indeed, this is a significant precedent case in the way of protecting the budget revenue base of the Russian Federation. The point is that according to the common rules, the permanent representative office of a corporation operating on the territory of the Russian Federation is treated as separate taxpayer at the place of its tax registration (i.e. in the Russian Federation) with regard to the revenues generated from business activities conducted on the territory of the Russian Federation and the related costs incurred by the representative office. The corporation itself is taxpayer at the place of tax registration, therefore the corporation's costs has nothing to do with the activities conducted by its permanent representative office. The permanent representative office is not legal entity, therefore the tax it has paid may be recognized as general liabilities on the profit (income) tax at the place of tax registration of the corporation itself. Prior to the foregoing court ruling was awarded, taxed revenues from selling goods imported by the TNC to the territory of the Russian Federation were considerably understated because expenses incurred by foreign entities of such corporations were deducted in their Russian representative offices. The 47 Moscow Tax Office (with which foreign companies are registered) reports that this scheme was employed by almost $90 \%$ of foreign companies. A similar channel for tax avoidance is employed through settlements between the head office and the subsidiaries (affiliated companies) of the corporation, which were established on the territory of the Russian Federation. In this case, all kinds of consulting agreements may be entered into, royalty payments for brand use effected, etc. A possibility to interdict such channels is reflected in the definition of expenses set forth in the Russian Tax Code (TC RF), which covers not only "documented" deductable expenses, but also "economically reasonable" expenses, i.e. the terms of exemption for such expenses were envisaged in the text thereof on the very date when the Tax Code was adopted, but thereafter courts were not ready to apply this regulation.

Another precedent case which is important in terms of protecting the interests of the Russian budget is a ruling of the Northwestern District Commercial Court (the court ruling dated 28 July 2015, case No. A56-

2 Shtykina A., Titov S., "Tax authorities win an emblematic dispute against a foreign law firm". Available at: top.rbc.ru/economic s/27/07/2015/55b64d8d9a7947ea1f7c9acd dated 27 July 2015. 
$61078 / 2014)$ which recognized as taxable income the capitalized interest paid to a foreign entity under a credit agreement. According to the terms of the credit agreement which was considered by the court at the hearing, the period of interest accrual to the foreign lender began from the date of loan and lasted until each calendar year. The interest must be added to the principal amount of the loan at the end of each calendar year.

The complainant - the foreign entity - filed a lawsuit against the tax office, alleging improper application of Clause 2, Article 287 and Clause 1, Article 310 of the TC RF. Under the foregoing provisions, the payment in cash (transfer of funds) or any other generation of income by the foreign entity is recognized as the time of profit taxation on the revenues of foreign organizations. According to the complainant, the tax office made a wrong decision on nonpayment of the tax and imposing penalties on the sums of the capitalized interest, because there was no actual payment of the sums to a non-resident.

The respondent - the tax office - established that the interest accrued to the lender was reflected as non-sale expenses of the borrower (interest payer), i.e. the borrower's tax base was reduced by these amounts. No ratified agreement between the Russian Federation and the foreign state in which the compliant (lender) is resident was available at the time of litigation, and therefore the results of the transaction must to the fullest extent be subject internal laws and regulations of the Russian Federation. The Commercial Court explained that Article 310 of the TC RF provides for other ways of income generation in addition to payment in cash. Capitalization of interest constitutes non-cash payment of income, for which reason at the time of capitalization of the accrued interest the borrower was actually acting as fiscal agent and was to charge tax on the income of the foreign entity (lender).

Following listed are some of the documents and decisions adopted in the period under review, which appear to be controversial and in some cases they may increase the risks of unstable budget system. This may subsequently harden the tax burden on taxpayers.

1. The Russian government proclaim steps towards the domestic market development. State-run companies are expected to be refocused on buying goods and services basically from domestic manufacturers. However, the Russian government have noted that they have no objective to ensure that imports are substituted by all means. As a reminder, this refers to purchases as part of investment projects, which are covered at the cost of the National Welfare Fund (NWF) and Vnesheconombank (VEB) ${ }^{1}$. There is a danger of low-quality import substitution resulting in losing the existing market outlets or lower technical characteristics of end products (works, services). We therefore consider it important that decisions on specific purchases should not be governed by political considerations.

Under the circumstances, there is a blend, typical of Russia, of the scheme of tender-based purchases at the cost of the budget with the State - a player (shareholder) - authoritarian imposition of additional limits on business activities of legally independent organizations. The State as a player (shareholder) must not interfere with the business run by a business entity (if business entities are state-run corporations, this is what we are supposed to be convinced of). Unfortunately, the State tends to interfere on a regular basis. As a result, incomes of state-run corporations are distributed outside of the Budget Law and their losses are covered at the cost of the budget.

2. Russian Government Executive Order dated 13 August 2015 No. 839 made amendments to Russian Government Executive Order of 14 August 2012 No. 825 , under which state guarantees only may be granted to certain organizations (to the extent that such organizations play a significant role in certain industries), even if their financial performance is poor including overdue liabilities to the Russian Federation, overdue compulsory payments to the budgets within the Russian budget system which a legal entity is unable to pay.

Nevertheless, this scheme has a positive aspect guarantees are denominated in the Russian national currency rather than foreign currencies (it is worth noting that the respective amendment was introduced as early as in 2014) and can be granted for a term of 3-7 years (this is very important in times of crisis).

It is our opinion that the scheme has much more controversial aspects. Guarantees may be granted to apparent bankrupts, perhaps, with a view to giving them another chance to obtain interest-bearing loans from banks (in other words, to cover their losses at the cost of persons who have deposits in such banks) and use the money to help them out until the guarantee expires. It is very likely that the guarantee will then be repaid by issuing securities and the interest due to the banks will be allowed to pay at the cost of the budget subsidies allocated for recapitalization. Despite the fact that guarantees may be granted until 31 October 2015, as set forth in the baseline Russian Government Executive Order dated 14 August 2012

1 "Russia's ban on imports of food products will not last forever - Medvedev", Available at: finmarket.ru/main/article/4082045 dated 11 August 2015. 
No. 825, the Russian government may at any time extend the term of granting guarantees by making changes though its executive order, because the text of the analyzed Executive Order has no reference to provisions of laws and regulations.

Of most risk, in our opinion, is the fact that the effective term of guarantees may end beyond (2018) the planned 3-year budget (especially if a guarantee is granted for a term of more than three years). Obligations under such long-term guarantees of the Russian government are simply presented at a certain point as accomplished fact by the Russian MinFin to the Federal Assembly of the Russian Federation (the State Duma and the Federation Council) for being legally implemented as part of the Federal Budget Law for the ensuing financial year ${ }^{1}$. This, in our opinion, infringement upon the rights of the Federal Assembly to set budget parameters based on proposals made by the Russian government in the course of budget hearing. The Russian government must grant guarantees either for the planning period (subject to a respective record in the budget text, specifying limits on the guarantees) or a long term under a special law or a Presidential executive order on the security of the entire property owned by the Russian Federation.

3. An updated version of Guidelines for the Tax Policy of the Russian Federation in 2016 and the Planning Period of 2017 and 2018 (hereinafter - the Tax Policy Guidelines) was published in the period under review. The proposed version contains basically all of the previously announced measures which were analyzed in our previous reviews, but there are some amendments which raise questions.

Clause 9.4. "Enhancing the rules of transfer pricing taxation" in the published updated version provides for restoring from 1 January 2016 the scheme of assessing the taxable profit of consolidated groups of taxpayers (CGTs) by recognizing losses of legally independent entities (organizations) inside CGTs by decreasing the income of profit-making CGT participants. The Russian government illustrate in the first part of the Tax Policy Guidelines $^{2}$ that the profit tax base assessment using CGTs has resulted in a decrease of the regional aggregate revenue base from the profit tax. At the same time, the Russian government have agreed, perhaps in an effort to accommodate loss-making mineral extraction monopolies, to restore from 1 January 2016 the consolidation of income and losses of CGT partici-

1 Paragraph 5 of the Russian Government Executive Order of 14 August 2012 No. 825 contains a strict prescription for the MinFin to "make provision for funds to honor obligations under guarantees granted in compliance with the Rules while drafting a federal budget bill for the ensuing financial year and the planning period."

2 Section II, Paragraph. 1 thereof. pants for profit tax purposes. The Tax Policy Guidelines provide for the possibility to recognize foreign trade transactions as controlled (transactions) as to the key export commodities (incl. crude oil and petroleum derivatives, iron and steel, non-ferrous metals, mineral fertilizers, precious metals and precious stones). This implies that tax authorities will be authorized to determine a market value for such transactions for taxation purposes, according to the provisions set forth in the TC RF.

The restoration of consolidation will result in unavoidable profit tax losses for the regional budgets, which might frustrate the regional population and governments. The Russian government amid crisis are openly protecting the economic interests of state-run corporations. In order to compensate the regional budgets for the profit tax revenue which have been lost because of eased off tax burden on CGTs, the Russian government have proposed that the land tax rate should be increased for lands occupied by federal entities (as a reminder, most of the considerable tax allowances concerning the corporate property tax of federal corporations were abolished in 2013: public railway tracks, cross-country pipelines, power transmission lines, facilities which are not their integral technological part, and the tax rate is to be gradually increased from $0.4 \%$ in 2013 to $2.2 \%$ in 2019 ; lands provided for national defense, security and customs purposes entered the list of items subject to the land tax at a rate not higher than $0.3 \%$ of the cadastral value) ${ }^{3}$. New tax allowances at the federal level (including tax exemptions, exemptions from the tax base and taxable items) are expected to be completely abolished for regional and local taxes in years to come.

The problem is that in a federal state it is the federal budget that pays the land and property taxes to the regional and local budgets for lands and assets being in use and/or managed by federal entities, and for the federal property (assets). At what cost will the federal budget be able amid crisis to increase amounts of its tax payments to the regional budgets? One can see that with the proposed decision on restoring from 1 January 2016 the profit tax consolidation rule for CGT members the Russian government have hardened the burden on the federal budget, which is not backed by revenue. This leads to the risk of underfunded social spending and higher budget deficit. The Russian government perhaps expect that such an indirect finan-

3 According to the estimates of the Russian Finance Ministry, shortfall revenue from the foregoing tax allowances at as of being in force in 2012 accounted for near $85 \%$ of the total shortfall revenue of the regional and local budgets from granting regional and local tax allowances at the federal level. 
cial support to state-run corporations will facilitate the investment activity of the latter ${ }^{1}$. However, this is not a solution to the issue of current financing of the widened gap between the federal budget revenue and expenditure.

The work on explaining the taxation stand of the Russian Finance Ministry and the Federal Tax Service (Russian FTS) continued in July-August 2015.

4. The Russian Finance Ministry and the Russian FTS published a package of explanations on how to pay the sales tax (Letters of the Russian Finance Ministry dated 15 July 2015 No. 03-11-09/40621 and the Russian FTS dated 12 August 2015 No. GD-4-3/14230; of the Russian Finance Ministry dated 23 July 2015 No. 03-1109/42494 and the Russian FTS dated 12 August 2015 No. GD-4-3/14233; of the Russian Finance Ministry and the Russian FTS dated 14 August 2015 No. GD-43/14386; of the Russian Finance Ministry dated 10 August 2015 No. 03-04-07/45937 and the Russian FTS dated 13 August 2015 No. $\Pi$ A-4-11/14285; of the Russian Finance Ministry dated 28 July 2015 No. 03-0310/43490; of the Russian FTS dated 12 August 2015 No. GD-4-3/14100).

The foregoing explain that the sales tax may reduce the profit tax (a single tax paid under the simplified taxation scheme) to the consolidated budget of the region in which a municipality is located and the sales tax has been paid by a CGT, and it also can be reduced under the simplified scheme of taxation according to the type of business activity which is subject to the sales tax which has been paid. It was explained how to record the sales tax in the tax return when the simplified taxation scheme is applied.

The amount of personal income tax may be reduced by the sum of sales tax and the paid sales tax may be recorded in the personal income tax return in accordance with the same rules which are applied to the profit tax.

With regard to participants of a consolidated group of taxpayers, the sales tax may be credited on an individual basis for each particular participant as taxpayer of the sales tax for each type of business activity on which the participant (taxpayer) has paid the sales tax, to the amount of the sum actually paid in the period elapsed since the beginning of the tax period. The CGT responsible participant may reduce the profit tax paid to the regional budget of a constituent entity of the

\footnotetext{
1 In practice, the presence of loss-making entities inside CGTs is evidence that the revenue from selling of raw materials have already been "dissolved" in these entities (this is because the expenses have to be covered by someone) and there is no way that they would be used for investment. Investment are made from the profit after tax and compensated by using depreciation which is included into the price of end products (works, services).
}

Russian Federation at the place of registration of a respective item which is subject to the sales tax.

The above procedure may not be applied if the taxpayer fails to notify of being registered as taxpayer of the sales tax with regard to the object of business activity for which the sales tax has been paid.

5. Letters of the Russian Finance Ministry and the Russian FTS dated 17 July 2015 No. 03-03-10/41223 and dated 14 August 2015 No. GD-4-3/14370 explained the terms of applying a $0 \%$ rate on the profit tax with regard to specific types of business activity.

In particular, it was explained that the TC RF provides for two independent arrangements which regulate the application of a $0 \%$ rate to the total income of an entity (organization):

- Article 284.1 which is applied to medical and educational activities;

- Article 284.5 which is applied to entities (organizations) involved in the provision of social services.

Each of the foregoing arrangements provides for applying a $0 \%$ rate to all generated income: in the former case, if the income generated from medical (or educational) activity account for at least $90 \%$ of the total income of an entity (organization); in the latter case, if the income from providing social services account for at least $90 \%$ of the total income of the entity (organization. According to the Russian Finance Ministry and the Russian FTS, there are no grounds to apply the $0 \%$ rate when the level of $90 \%$ is achieved exclusively subject to summing the shares of income from medical (or educational) activities and social service provision.

6. Letters of the Russian Finance Ministry dated 06 July 2015 No. 03-11-09/38742 and the Russian FTS dated 12 August 2015 No. GD-4-3/14231 explain how to apply the patent scheme of taxation. The fact of overdue payment for a patent for the previous period may constitute grounds for patent refusal in the ensuing calendar year. It is set forth in Sub-clause 3, Clause 6, Article 346.45 of the TC RF that the taxpayer shall be deemed to have forfeited the right to apply the patent scheme of taxation and switched to the standard taxation scheme since the beginning of the fiscal period for which the taxpayer was patented. Individual entrepreneurs who apply the patent taxation scheme may be deregistered with a tax authority within five days after the date of payment for the patent expires.

7. Disputable is the stand of the Russian Finance Ministry on allocating the interest on a loan obtained for paying out dividends to the expenses which are considered when the profit tax base is assessed, which was explained in Ministry's Letter No. 03-0306/1/42780 dated 24 July 2015. 
In support of its stand the Finance Ministry duplicates textually Ruling No. 3690/13 which was awarded on 23 July 2013 by the Presidium of the Supreme Commercial Court of the Russian Federation (SCC): "Dividends paid to participants of business entities represent the profit distributed among them, which has been generated as a result of business activities. In this context the obligation to pay dividends may not be treated as (obligation) assumed without any relation to profit-making activities". In other words, the SCC Presidium interprets expenses related to payment of dividends as (expenses) related to business activities. Furthermore, the SCC Presidium does not treat the dividends as expenses which reduce the tax base, due, perhaps, to the fact that under Clause 1 Article 270 such expenses "shall not be considered in determining the profit tax base".

Unfortunately, we are facing a situation when court decisions fail to consider the economic nature of transactions. Not any amount debited from the account of an organization may be treated as expenses related to business activities and must decrease the profit tax base. Some of the expenses are covered from the profit after tax, namely expenses which are not related to business activities, profit-making. Supposing that a company (entity) conducts business activities but has no sufficient funds to keep the process on an ongoing basis. In this case, the company (entity) seeks and obtains an interest-bearing loan. The interest on the loan also become business-related expenses, because the borrower pays the interest to the lender on account of distributing the profit which the bor- rower made from selling products (so-called non-sale expenses). But if business-related settlements have been completed in full, the profit estimated and the profit tax paid, then all subsequent payments and settlements from this part of the profit are simply a form of subsequent distribution which is not related to business (the profit-making activity has come to an end). Not the entire net profit is distributed as dividends. Shareholders decide how and where the net profit is to be distributed, and it is shareholders who are to decide how much money is to be paid as dividends, on payment for bank services of crediting funds to personal accounts of shareholders, and how much money is to be capitalized (i.e. how much money is to be retained as equity).

Unfortunately, the stand of the SCC Presidium may result in confusion and trigger a great deal of violent interpretations of deductable corporate costs when the profit tax base is assessed. In its explanation the Russian Finance Ministry accepted the possibility of paying dividends with raised funds (loans) (i.e. dividends would be paid in the absence of profits ${ }^{1}$ ). It is unacceptable, in our opinion, that the key financial authority uses in its official explanation the speech pattern of that dividends may be paid with raised funds. It is our opinion that the judicial system and the core financial authorities will have to turn back to this matter (distribution of dividends after tax) and analyze the issue of engaging independent experts.

1 Это уже будет не выплата дивидендов, а намерение передать в собственность третьим лицам third-party money. 